Hodgskiss, M.S.W., and Sperling, E.A., 2021, A prolonged, two-step oxygenation of Earth's early atmosphere:

Support from confidence intervals: Geology, https://doi.org/10.1130/G49385.1

\title{
A prolonged, two-step oxygenation of Earth's early atmosphere: support from confidence intervals
}

Malcolm S.W. Hodgskiss ${ }^{1}$, Erik A. Sperling ${ }^{2}$

${ }^{1}$ Department of Earth Sciences, University of Cambridge, Cambridge, CB2 3EQ, United Kingdom

${ }^{2}$ Department of Geological Sciences, Stanford University, Stanford, California, 94305, United

States of America 


\section{DATA COMPILATION}

MIF-S data were taken from the Global Sedimentary Sulphur Isotope Database (Vikraman et al.), and more recently published data (e.g., Poulton et al., 2021). Age constraints were verified from primary literature. Compilation efforts for red beds and $\mathrm{I} / \mathrm{Ca}+\mathrm{Mg}$ ) focused on the Paleo- and Mesoproterozoic, as temporally-distant units have diminishing importance for CI calculations. The full set of data used is available as a supplementary Excel file.

\section{COMPLICATIONS IN REGIONAL GEOLOGY}

Many of the Paleoproterozoic successions discussed here have very complex regional geology, whose stratigraphic correlation and/or understanding is exacerbated by poor outcropping

and a reliance on drill cores. Consequently, a number of fundamental uncertainties remain, some of which are briefly summarised below. To minimise uncertainties, we attempted to use the most upto-date published geological correlations and geochronological data, rather than relying on ages reported in MIF-S/RSDM/Red bed/I/(Ca+Mg) literature that may be outdated. In an attempt to further minimise uncertainties, no dates were used that are based on the correlation of events that have not yet been conclusively demonstrated as globally synchronous and correlatable, specifically, Paleoproterozoic 'Snowball' glaciations and the Lomagundi-Jatuli carbon isotope excursion. Here we present several examples of such complications, while noting that this list is not exhaustive.

\section{Correlation of Duitschland and Rooihoogte formations, Pretoria Group}

Debate has persisted for several decades over whether the Duitschland and Rooihoogte formations were deposited contemporaneously and can be laterally correlated (summarised in Warke and Schröder, 2018). This is of particular importance as both formations record a transition from MIF-S to MDF-S; if they are not coeval then it would imply highly variable MIF-S recycling over 
regional scales, or multiple MIF-S to MDF-S transitions. Studies constraining the onset of the GOE do not take a consistant stance on whether these units are coeval (cf. Bekker et al., 2004; Luo et al., 2016; Gumsley et al., 2017; Warke et al., 2020), although Poulton et al. (2021) showed that MIF-S occurs in units overlying the Duitschland/Rooihoogte formations.

\section{Correlation of Paleoproterozoic 'Snowball' glacial deposits}

There have been many efforts to correlate Paleoproterozoic regions across continents and around the world on the basis of diamictite units interpretted as glacial in origin. While the onset and termination of Neoproterozoic Snowball Earth glaciations have been demonstrated as globally synchronous (e.g., Rooney et al., 2015), the comparatively sparse geochronological controls on the Paleoproterozoic glacial deposits do not yet permit such an interpretation, particularly as there is not a consensus on the exact number of global glaciations during the Paleoproterozoic (reviewed in Young, 2014; 2019). For example, the apparent 'fourth' (final) glacial event is only recorded in South Africa (Poulton et al., 2021). However, we note that we do not use any age constraints in this study that rely upon the correlation of glacial deposits between different regions.

\section{The duration of Turee Creek Group deposition}

There has been discusson over whether the Turee Creek Group in Australia records deposition spanning hundreds of Myr, or just tens of Myr (reviewed in Caquineau et al., 2018). Some (e.g., Krapež, 2017) have argued for deposition spanning just several tens of Myr, from ca. 2.45 to 2.43 Ga. However, newer Re-Os and detrital zircon U-Pb geochronology indicates that the Meteorite Bore Member was deposited ca. 2.31 Ga (Philippot et al., 2018; Caquineau et al., 2018), suggesting that deposition of the Turee Creek Group spans at least $>100 \mathrm{Myr}$, although there is a major unconformity between it and the overlying Beasley River Quartzite (maximum depositional age of ca. 2.33 Ga; Caquineau et al., 2018) and Cheela Springs Basalt (deposited ca. 2.209 Ga; Martin et 
al., 1998), meaning the unconformity may represent an interval up to 100 Myr. Significantly, these improved age constraints suggest that the Turee Creek Group spans $\geq 140 \mathrm{Myr}$, rather than tens of Myr.

\section{Reliance on drill cores}

Many of the successions studied here outcrop poorly, and therefore heavily rely on material obtained from drill core, potentially hindering correlation of units or observation of large scale features not discernable through material collected from scattered drilling programs. This could have potentially large consequences when correlating geochronological dates from core and outcrop to geochemical data collected from other cores or outcrops. As an example, the MIF-S to MDF-S transition documented by Warke et al. (2020) in the FAR-DEEP 1A and 3A cores relies on dates from four studies, one of which dated material from outcrop and drill core (age of the crystalline basement underlying the Seidorechka Sedimentary Formation, and a maximum depositional age of Polisarka Sedimentary Formation; Amelin et al., 1995), one from outcrop (age of volcanic unit within the upper Seidorechka Sedimentary Formation; Chashchin et al., 2008), one with material collected from FAR-DEEP core 3A itself (age of tuff in Polisarka Volcanic Formation; Brasier et al., 2013), and one with an unspecified material source (age of instrusive unit cross-cutting Seidorechka Volcanic Formation; Vrevskii et al., 2009). It is therefore essential that the stratigraphic relations between these different sample localities (whether outcrop or drill core) are well understood.

\section{Ambiguous red beds}

The Koegas Subgroup of South Africa contains some of the oldest putative red beds (ca. 2.436 - 2.426 Ga; Schröder et al., 2011; Schier et al., 2018), although there remains some debate whether or not they are truly 'red beds'. Schröder et al. (2011) suggested a possible red bed origin 
on the basis of petrographic observations that indicated the mobilisation and oxidation of iron during early diagenesis. Subsequent investigations of the Koegas Subgroup by Johnson et al. $(2013,2014)$ reported granular iron formation rather than red beds, and inferred very low atmospheric oxygen levels during deposition of the Koegas Subgroup. Gumsley et al. (2017) indicated that the red beds in the Koegas Subgroup were ambiguous, although without supporting evidence. While this discussion has focused on the Koegas Subgroup, it is likely that other formations would be subject to similar dispute, were they subject to similarly detailed and frequent investigations by different researchers. To determine if inclusion/exclusion of the Koegas Subgroup from the red bed compilation has a significant impact on the confidence interval results, analyses were conducted both with and without this unit (results summarised in Table DR1).

Table DR1. Confidence interval results for first appearance of red beds, both including and excluding the Koegas Subgroup.

\begin{tabular}{|c|c|c|c|c|}
\hline $\begin{array}{c}\text { Geological/ } \\
\text { geochemical } \\
\text { proxy }\end{array}$ & $\begin{array}{c}\text { Median } \\
\text { first } \\
\text { occurrence }\end{array}$ & $\begin{array}{c}\text { Appearance } \\
\text { using CE method } \\
\mathbf{1 \sigma}(\mathbf{2 \sigma})\end{array}$ & $\begin{array}{c}\text { Appearance } \\
\text { using OLE } \\
\text { method } \\
\mathbf{1 \sigma}(\mathbf{2} \boldsymbol{\sigma})\end{array}$ & $\begin{array}{c}\text { Solution space } \\
\mathbf{1 \sigma} \mathbf{( 2 \sigma})\end{array}$ \\
\hline $\begin{array}{c}\text { Red beds } \\
\text { (including } \\
\text { Koegas }\end{array}$ & $2477 \mathrm{Ma}$ & $\begin{array}{c}2814 \mathrm{Ma} \\
(2899 \mathrm{Ma})\end{array}$ & $\begin{array}{c}2551-2483 \mathrm{Ma} \\
(2632-2477 \mathrm{Ma})\end{array}$ & $\begin{array}{c}2983-2425 \mathrm{Ma} \\
(3156-2422 \mathrm{Ma})\end{array}$ \\
$\begin{array}{c}\text { Subgroup) } \\
\text { Red beds } \\
\text { (excluding } \\
\text { Koegas } \\
\text { Subgroup) }\end{array}$ & $2478 \mathrm{Ma}$ & $\begin{array}{c}2818 \mathrm{Ma} \\
(2904 \mathrm{Ma})\end{array}$ & $\begin{array}{c}2572-2488 \mathrm{Ma} \\
(2665-2479 \mathrm{Ma})\end{array}$ & $\begin{array}{c}3019-2301 \mathrm{Ma} \\
(3205-2299 \mathrm{Ma})\end{array}$ \\
\hline
\end{tabular}

As shown in Table DR1, exclusion of the Koegas Subgroup from confidence interval calculations actually shifts the hypothesised first appearance of red beds to slightly earlier in Earth history, rather than later. In any case, the exclusion of the Koegas Subgroup results in relatively minor shifts in 
confidence intervals, and does not substantially alter support for a two-step Great Oxidation Event, as discussed in the main text.

\section{CONFIDENCE INTERVAL CALCULATION}

The following methods were carried out to evaluate confidence intervals (CIs) for the $68^{\text {th }}$ and $95^{\text {th }}$ percentiles ( $1 \sigma$ and $2 \sigma$, respectively).

\section{Classical Estimation Method}

Following Strauss and Sadler (1989), confidence intervals are calculated as:

$$
\alpha=(1-\mathrm{C})^{-1 /(\mathrm{H}-1)}-1
$$

where $\alpha$ is the confidence interval expressed as a fraction of the stratigraphic height (or time interval), $\mathrm{C}$ is the chosen confidence interval (e.g., $2 \sigma-0.95)$, and $\mathrm{H}$ is the number of occurrences of interest. The confidence interval is then determined by multiplication of $\alpha$ with the time interval.

\section{Optimal Linear Estimation Method}

Using the Optimal Linear Estimation Method, we follow Roberts and Solow (2003). The ages of occurrences, $T$, are in reverse chronological order, where the number of occurrences in $T$, $k$, are 'weighted' such that the latest occurrences are more important in constraining the time of disappearance.

The vector of weights, $a$, is calculated as follows:

$$
a=\left(e^{\mathrm{t}} \Lambda^{-1} \mathrm{e}\right)^{-1} \Lambda^{-1} e
$$

where $e$ is a vector of ones with length $k$, and $\Lambda$ is a symmetric matrix with dimensions $k$ by $k$ where elements are calculated:

$$
\lambda_{\mathrm{i}, \mathrm{j}}=(\Gamma(2 v+i) \Gamma(v+j)) /(\Gamma(v+i) \Gamma(j))
$$

where $\Gamma$ is the standard gamma function. To calculate $v$ : 


$$
v=1 /(k-1) \sum_{\mathrm{i}-1}{ }^{\mathrm{k}-2} \ln \left(\left(T_{1}-T_{\mathrm{k}}\right) /\left(T_{1}-T_{\mathrm{i}+1}\right)\right)
$$

The confidence interval is then calculated as:

$$
\left(T_{1}+\left(T_{1}-T_{\mathrm{k}}\right) /\left(S_{\mathrm{L}}-1\right), T_{1}+\left(T_{1}-T_{\mathrm{k}}\right) /\left(S_{\mathrm{U}}-1\right)\right.
$$

where $S_{\mathrm{L}}$ and $S_{\mathrm{U}}$ are calculated as:

$$
\begin{aligned}
& S_{\mathrm{L}}=(-\ln (1-\alpha / 2) / k)^{-v} \\
& S_{\mathrm{U}}=(-\ln (\alpha / 2) / k)^{-v}
\end{aligned}
$$

where $\alpha$ is the confidence interval. 

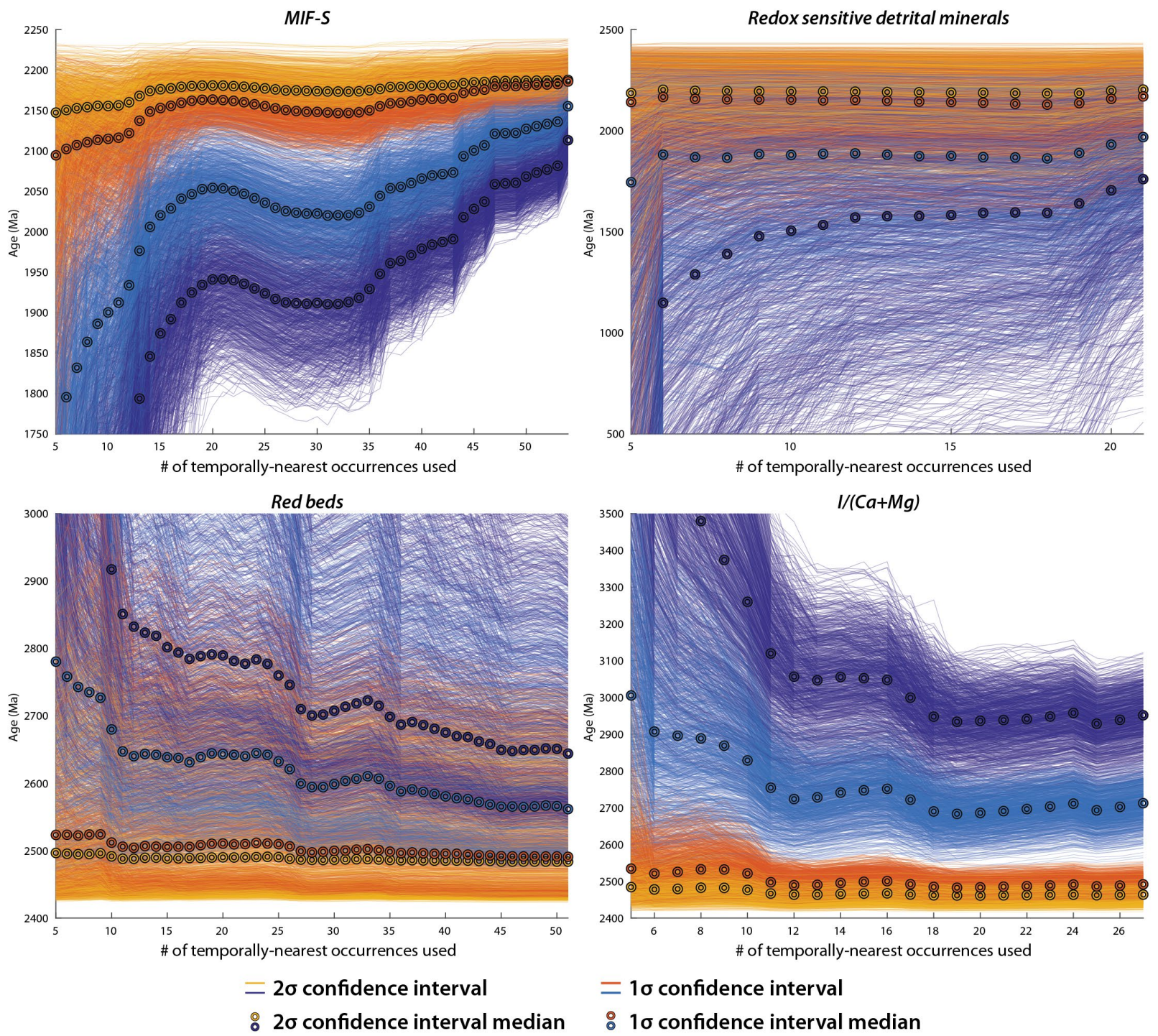

$=1 \sigma$ confidence interval

: $1 \sigma$ confidence interval median 


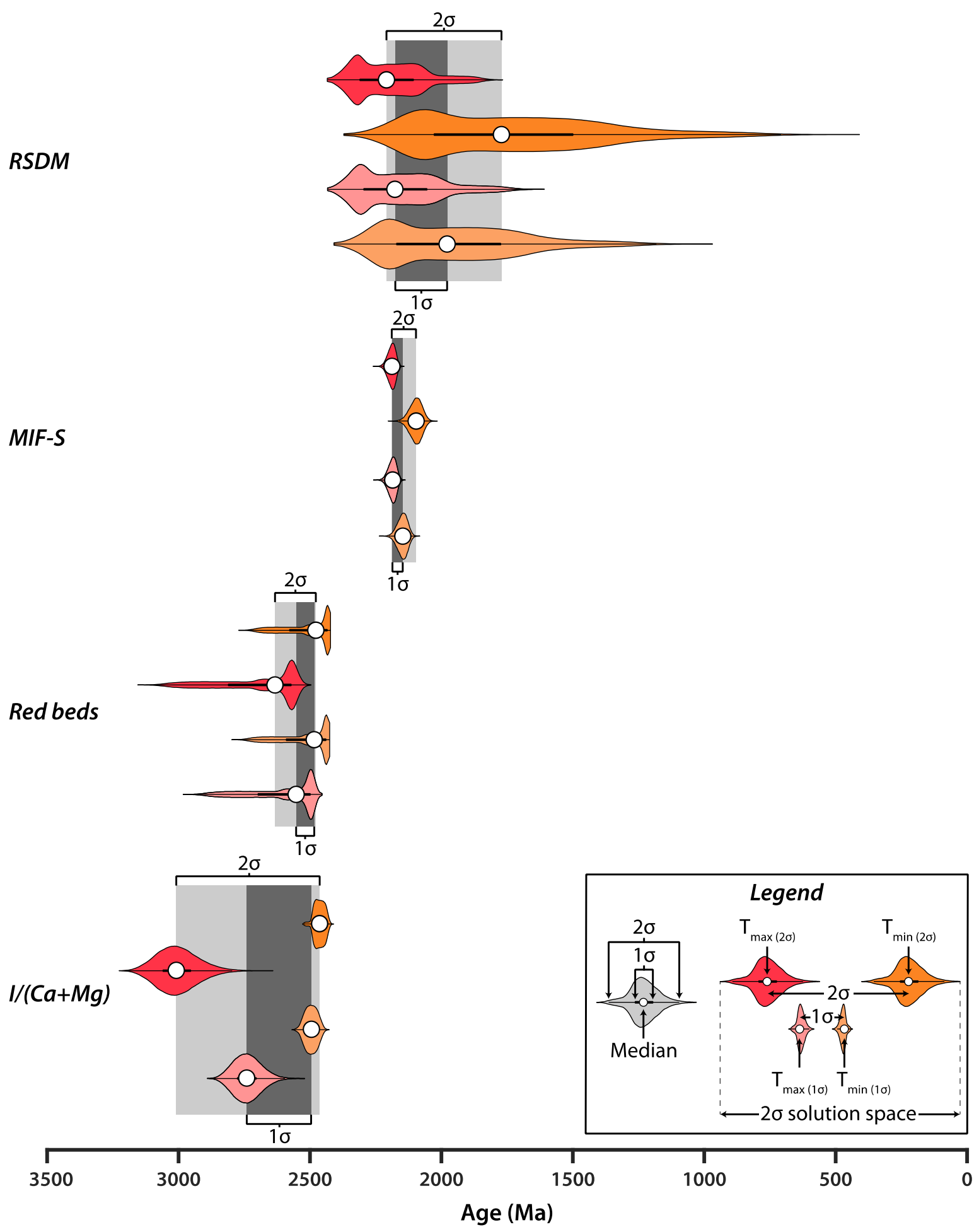

Figure DR2. 'Violin plots' depicting the results of 50,000 repeat analyses using the OLE method for RSDM, MIF-S, red beds, and I/(Ca+Mg). The start and stop of the $2 \sigma$ confidence intervals are shown in dark red and dark orange, respectively, with the interval between the median of each 
being the $2 \sigma$ confidence interval discussed in the main text (indicated by a light grey box). The start and stop of the $1 \sigma$ confidence intervals are shown in lighter red and orange, respectively, and the interval between the median of each (indicated by a darker grey box) is the $1 \sigma$ confidence interval discussed in the main text. 


\section{REFERENCES}

Amelin, Y.V., Heaman, L.M. and Semenov, V.S., 1995, U-Pb geochronology of layered mafic intrusions in the eastern Baltic Shield: implications for the timing and duration of Paleoproterozoic continental rifting: Precambrian Research, v.75, p.31-46.

Bekker, A., Holland, H.D., Wang, P.L., Rumble, D.I.I.I., Stein, H.J., Hannah, J.L., Coetzee, L.L. and Beukes, N.J., 2004, Dating the rise of atmospheric oxygen: Nature, v.427, p.117-120.

Brasier, A.T., Martin, A.P., Melezhik, V.A., Prave, A.R., Condon, D.J., Fallick, A.E. and Scientists, F.D., 2013, Earth's earliest global glaciation? Carbonate geochemistry and geochronology of the Polisarka Sedimentary Formation, Kola Peninsula, Russia:

Precambrian Research, v.235, p.278-294.

Caquineau, T., Paquette, J.L. and Philippot, P., 2018, U-Pb detrital zircon geochronology of the Turee Creek Group, Hamersley Basin, Western Australia: timing and correlation of the Paleoproterozoic glaciations: Precambrian Research, v. 307, p.34-50.

Chashchin, V.V., Bayanova, T.B. and Levkovich, N.V., 2008, Volcanoplutonic association of the early-stage evolution of the Imandra-Varzuga rift zone, Kola Peninsula, Russia: Geological, petrogeochemical, and isotope-geochronological data: Petrology, v.16, p.279298.

Gumsley, A.P., Chamberlain, K.R., Bleeker, W., Söderlund, U., de Kock, M.O., Larsson, E.R. and Bekker, A., 2017, Timing and tempo of the Great Oxidation Event: Proceedings of the National Academy of Sciences, v. 114, p. 1811-1816.

Johnson, J.E., Gerpheide, A., Lamb, M.P. and Fischer, W.W., 2014, $\mathrm{O}_{2}$ constraints from Paleoproterozoic detrital pyrite and uraninite: Geological Society of America Bulletin, v. 126, p. 813-830. 
Johnson, J.E., Webb, S.M., Thomas, K., Ono, S., Kirschvink, J.L. and Fischer, W.W., 2013, Manganese-oxidizing photosynthesis before the rise of cyanobacteria: Proceedings of the National Academy of Sciences, v.110, p. 11238-11243.

Ketchum, K.Y., Heaman, L.M., Bennett, G. and Hughes, D.J., 2013, Age, petrogenesis and tectonic setting of the Thessalon volcanic rocks, Huronian Supergroup, Canada: Precambrian Research, v. 233, p.144-172.

Krapež, B., Müller, S.G., Fletcher, I.R. and Rasmussen, B., 2017, A tale of two basins? Stratigraphy and detrital zircon provenance of the Palaeoproterozoic Turee Creek and Horseshoe basins of Western Australia: Precambrian Research, v.294, p.67-90.

Luo, G., Ono, S., Beukes, N.J., Wang, D.T., Xie, S. and Summons, R.E., 2016, Rapid oxygenation of Earth's atmosphere 2.33 billion years ago: Science Advances, v. 2, p.e1600134.

Martin, D.M., Li, Z.X., Nemchin, A.A. and Powell, C.M., 1998, A pre-2.2 Ga age for giant hematite ores of the Hamersley Province, Australia?: Economic Geology, v.93, p.10841090 .

Philippot, P., Ávila, J.N., Killingsworth, B.A., Tessalina, S., Baton, F., Caquineau, T., Muller, E., Pecoits, E., Cartigny, P., Lalonde, S.V. and Ireland, T.R., 2018, Globally asynchronous sulphur isotope signals require re-definition of the Great Oxidation Event: Nature Communications, v. 9, p. 1-10.

Poulton, S.W., Bekker, A., Cumming, V.M., Zerkle, A.L., Canfield, D.E. and Johnston, D.T., 2021, A 200-million-year delay in permanent atmospheric oxygenation: Nature, v.592, p.232-236. 
Rasmussen, B., Bekker, A. and Fletcher, I.R., 2013, Correlation of Paleoproterozoic glaciations based on U-Pb zircon ages for tuff beds in the Transvaal and Huronian Supergroups: Earth and Planetary Science Letters, v.382, p.173-180.

Roberts, D.L. and Solow, A.R., 2003, When did the dodo become extinct?: Nature, v.426, p.245245.

Rooney, A.D., Strauss, J.V., Brandon, A.D. and Macdonald, F.A., 2015, A Cryogenian chronology: Two long-lasting synchronous Neoproterozoic glaciations: Geology, v.43, p.459-462.

Schier, K., Bau, M., Muenker, C., Beukes, N. and Viehmann, S., 2018, Trace element and Nd isotope composition of shallow seawater prior to the Great Oxidation Event: Evidence from stromatolitic bioherms in the Paleoproterozoic Rooinekke and Nelani Formations, South Africa: Precambrian Research, v.315, p.92-102.

Schröder, S., Bedorf, N.J., Beukes, N.J. and Gutzmer, J., 2011, From BIF to red beds:

Sedimentology and sequence stratigraphy of the Paleoproterozoic Koegas Subgroup (South Africa): Sedimentary Geology, v.236, p.25-44.

Strauss, D. and Sadler, P.M., 1989, Classical confidence intervals and Bayesian probability estimates for ends of local taxon ranges: Mathematical Geology, v.21, p.411-427.

Vikraman, S., Caruso, S., Fiorentini, M.L. and LaFlamme, C., 2019, The Global Sedimentary Sulfur Isotope Database: http://www.cet.edu.au/research-projects/special-projects/gssidglobal-sedimentary-sulfur-isotope-database (accessed July 15th, 2020).

Vrevskii, A.B., Bogomolov, E.S., Zinger, T.F. and Sergeev, S.A., 2010, Polychronic sources and isotopic age of the volcanogenic complex (Arvarench Unit) of the Imandra-Varzuga structure, Kola Peninsula: Doklady Earth Sciences v.431, p.386-389. 
Warke, M.R., Di Rocco, T., Zerkle, A.L., Lepland, A., Prave, A.R., Martin, A.P., Ueno, Y., Condon, D.J. and Claire, M.W., 2020, The Great Oxidation Event preceded a Paleoproterozoic "snowball Earth": Proceedings of the National Academy of Sciences, v.117, p.13314-13320.

Warke, M.R. and Schröder, S., 2018, Synsedimentary fault control on the deposition of the Duitschland Formation (South Africa): Implications for depositional settings, Paleoproterozoic stratigraphic correlations, and the GOE: Precambrian Research, v.310, p.348-364.

Young, G.M., 2014. Contradictory correlations of Paleoproterozoic glacial deposits: Local, regional or global controls?: Precambrian Research, v.247, p.33-44.

Young, G.M., 2019. Aspects of the Archean-Proterozoic transition: How the great Huronian Glacial Event was initiated by rift-related uplift and terminated at the rift-drift transition during break-up of Lauroscandia: Earth-Science Reviews, v.190, p.171-189. 